\title{
COVID-19 and Strategies for Its Therapeutics
}

\author{
Fayang Ma, ,a,b Tingxuan Gu, a,b Simin Zhao,, ${ }^{a, b}$ Kangdong Liu,a,b,c,d \& Zigang Donga,b,* \\ aDepartment of Pathophysiology, School of Basic Medical Sciences, College of Medicine, Zhengzhou University,

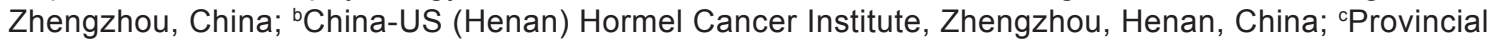 \\ Cooperative Innovation Center for Cancer Chemoprevention, Zhengzhou University, Zhengzhou, China; \\ ${ }^{\mathrm{d}}$ Cancer Chemoprevention International Collaboration Laboratory, Zhengzhou, China \\ *Address all correspondence to: Zigang Dong, Department of Pathophysiology, School of Basic Medical Sciences, College of Medicine, Zhengzhou \\ University, Zhengzhou, 450008, China; Tel.: +86-371-65587276, E-mail: dongzg@zzu.edu.cn
}

\begin{abstract}
Currently the epidemic of SARS-CoV-2-caused COVID-19 is a major threat to global public health. The latest clinical data, laboratory results, and autopsy information are summarized herein to provide a brief review of the significant issues surrounding SARS-CoV-2 and COVID-19. In this review, we also cover research on the ways in which the virus enters the human body, general clinical symptoms, immunopathological responses in severe cases of COVID-19, and the issues surrounding the potential therapeutic responses to the illness.
\end{abstract}

KEY WORDS: COVID-19, SARS-CoV-2, therapeutics, clinical trial, vaccine

\section{THE ONGOING WORLDWIDE EPIDEMIC OF COVID-19}

Currently, people throughout the world are suffering from a highly contagious plague caused by the severe acute respiratory syndrome coronavirus 2 (SARS-CoV-2), with an average mortality rate of $3.06 \%(979,212$ out of $32,029,704)$. This is devastatingly high, particularly for countries such as the United Kingdom, where 41,862 out of the total 409,733 certified cases $(10.21 \%)$ were killed by coronavirus disease (COVID-19). The current mortality rate for the United States, as reported by the World Health Organization (WHO), is 2.92\% (200,725 out of $6,868,828$ confirmed cases) as of September 25, 2020. ${ }^{1}$ Although these high mortality rates are not expected to be maintained as testing becomes more widely available, the impact of the increasing total numbers of confirmed cases is nonetheless dreadful for everyone. Scientists throughout the world are working tirelessly to identify effective and safe therapeutics for the pneumonia caused by SARS-CoV-2, including vaccine development, assessing the potential use of statins, anti-HIV drugs, and immune-based therapies.

\section{THE VIRUS'S ENTRY INTO THE HUMAN BODY: JUST THE BEGINNING}

In December 2019, the virus strain of SARS-CoV-2 was first isolated from the human airway epithelial cells and was later identified as a new clade within the sarbecovirus subgenus. SARS-CoV-2 is a positive-sense single-stranded RNA virus and is the seventh most infectious member in the coronavirus family. ${ }^{2}$ The genome of the virus was compared with SARS-CoV and MERS-CoV, and the homology was about $79 \%$ and $50 \%$, respectively. Thus it was named as novel coronavirus, or SARS-CoV-2. ${ }^{3}$ Generally, SARS-CoV-2 is structurally composed of spike protein $(\mathrm{S})$, envelope protein $(\mathrm{E})$, membrane protein $(\mathrm{M})$, and nucleocapsid $(\mathrm{N})$.

Human angiotensin converting enzyme 2 (ACE2) is well-known for its role in the renin-angiotensin-aldosterone system, which is essential for the regulation of systemic blood pressure and renal function. Increasing evidence has added a level of complexity to ACE2's new functions in pathological processes, for which it serves as a receptor for direct binding with different strains of coronavirus, including SARS and NL6. ${ }^{4}$ The highly infectious nature of coronavirus stems from the high binding affinity 
between ACE2 and the receptor binding domain (RBD) of SARS-CoV-2 S proteins. The entry process is also facilitated by transmembrane protease serine 2 (TMPRSS2) exposing a fusion sequence, a fundamental step for the binding-fusion-entry processes. ${ }^{5}$ In the cells infected by coronavirus, the pathogen-associated molecular patterns (PAMPs) of the viral nucleic acids are sensed and recognized by specific pathogen recognition receptors (PRRs). RIG-1s, like helicase MDA5, PKR, and OAS, are involved in the recognition events. ${ }^{6}$ The interferons could be produced by the infected epithelial cells and induce innate immune responses, and the TLR3/ TLR4 adaptor TRIF participates in the immune responses after the SARS-CoV infection. ${ }^{\text {? }}$

ACE2 has been identified as the receptor for SARS-CoV-2 to enter human lung cells, ${ }^{8,9}$ which is expressed in multiple human organs, such as certain cell types within the pulmonary, intestines, kidney, heart, and testis. ${ }^{10}$ This may explain why viral particles can be detected in the expectorations, feces, and semen of the infected population, and consequently, semen and prostate secretion should also be further explored. ${ }^{11-13}$ The wide distribution of infections possibly could be explained by a recent in vitro study in which host cells were infected and manipulated to bud filopodia protrusions carrying viral particles to infect the surrounding cells; the CK2 was also contained in the protrusions. ${ }^{14}$

Extended human activities occupied and caused permanent damage to the territories of wild animals, which possibly broke the strict infectivity barriers between humans and species of bats. In recent years, many novel strains of the virus have been identified in wild animals like Chinese horseshoe bats, ${ }^{15}$ showing varying degrees of homologies of the already-known contagious virus; these should be monitored to prevent the outbreak of new rounds of virus-induced epidemics. ${ }^{16-18}$

\section{THE CLINICAL SYMPTOMS OF COVID-19 AND UNDERLYING MOLECULAR ATTRIBUTES}

The common clinical symptoms of COVID-19 are mainly caused by abnormalities in the respiratory system, gastrointestinal system, and cardiovascular system. Other symptoms from thrombotic complications are also commonly observed in COVID-19 patients (Fig. 1). Different levels of severity are also observed in COVID-19 patients, with more than $80 \%$ of patients only experiencing mild to moderate symptoms, without the need for hospitalization. ${ }^{19}$

The existence of viral particles has been recorded in respiratory, feces, and other samples (Fig. 1), ${ }^{11-13}$ and the nasal tract was proposed as the first viral bank for invasion into the human body. ${ }^{20}$ Higher viral loads were found in the nasal swab compared with pharyngeal ones. ${ }^{11}$ Thus the fluids and secretions from the nose should be properly managed to avoid further infections, and mask protections are strongly recommended for high-risk districts. However, a negative nasopharyngeal swab test does not guarantee that an individual is free of viral infection, for in some postmortem tests of COVID-19 patients, the viral nucleic acid was shown to be negative. ${ }^{21}$ Thus the swab test and blood test should be combined to increase the accuracy of screening and diagnosis.

The first three reported COVID-19 patients showed the clinic symptoms of fever and cough, and with bilateral fluffy opacities in chest radiographs, 7 days after the initial report of discomfort on December 20, 2019. One patient developed respiratory distress and died on January 9, 2020, only 20 days from the onset of clinical symptoms, thus indicative of the rapid nature of the disease's progression. ${ }^{2}$ A relatively detailed investigation was performed in a cohort of 41 hospitalized patients with COVID-19. It only took an average of 2 days from hospital admission to acute respiratory distress syndrome (ARDS), and $15 \%$ patients died from this. All 41 patients had pneumonia, presenting in CT images as ground-glass opacities. ${ }^{22}$ The most common clinical symptoms were fever $(98 \%)$, cough $(76 \%)$, fatigue (44\%), and dyspnea $(55 \%){ }^{22}$ In another bigger cohort study, 452 patients with COVID-19 were recruited; fever $(92.6 \%)$, shortness of breath $(50.8 \%)$, fatigue $(46.4 \%)$, expectoration $(41.4 \%)$, dry cough (33.3\%), and diarrhea (26.7\%) were the most common symptoms. ${ }^{23}$ The underlying mechanism and exact pathological changes should be clarified as soon as possible. 


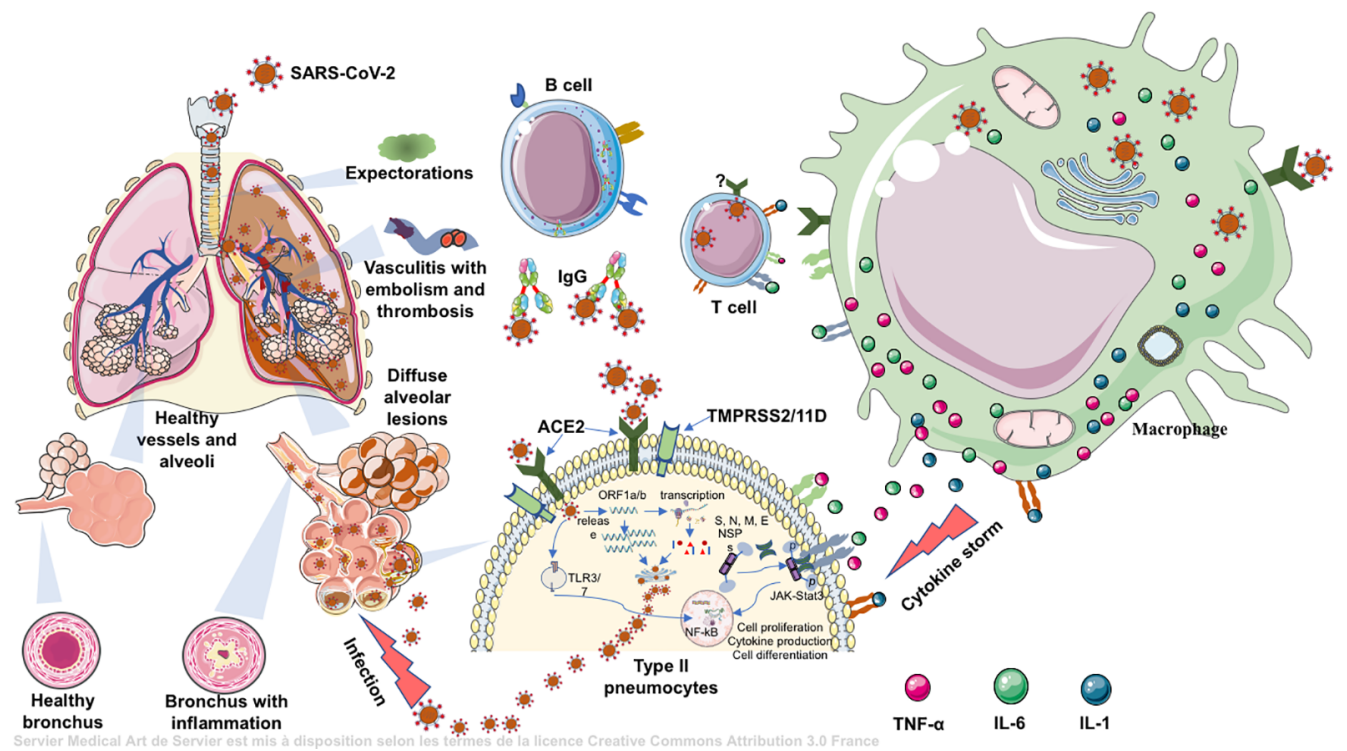

FIG. 1: Common clinical symptoms of COVID-19 in the respiratory system, gastrointestinal system, and CNS system, along with other symptoms from thrombotic complications. The different levels of severity were also observed in COVID-19 patients (cited image of the male body is available from https://www.proteinatlas.org/ ENSG00000130234-ACE2/tissue\#cbox).

In the serum of COVID-19 patients, increased levels of IL-1, IL-2, TNF- $\alpha$, and IL-6 all served as endogenous pyrogen, acting on the thermoregulation center hypothalamus, increasing the body temperature for more effective immune response, and finally causing fever, as is common in COVID-19 patients. ${ }^{23}$ IL-1 $\beta$ associates with hyperalgesia (increased sensitivity to pain) were also increased in COVID-19 patients, probably underlying the myalgia symptoms of the patients. ${ }^{23}$ The increased neutrophil-to-lymphocyte ratio (NLR) and levels of procalcitonin cause potential bacterial coinfection due to the dysfunctions of the immune system in COVID-19, which could possibly cause pneumonia in the lung. ${ }^{23}$ In addition, the high serum level of C-reactive proteins (CRP) in COVID-19 patients also increased, which is possibly caused by macrophage activation syndrome and bacteria coinfections, but not common in virus infections. ${ }^{24}$

The incidence of diarrhea was more frequent (26.7\%) in the cohort of 452 COVID-19 patients; this could possibly be explained by ACE2 as a common receptor for SARS-CoV-2 and SARS-CoV, highly expressed in the gastrointestinal tract. ${ }^{10}$ The ACE2 expression in lung tissue is at a much lower level than it is in the intestine. ${ }^{10}$ In addition to ACE2 and TMPRSS2, other unknown mechanisms facilitating the entry of the virus into mammalian cells warrant further exploration to clarify why the lower respiratory tract is the most commonly injured site, aside from the upper respiratory tract. Recent research has challenged the idea that the lower respiratory tract is a major targeted site, with evidence demonstrating higher infectivity in the nose compared with the lower pulmonary sites, along with a higher expression of ACE2 in the nasal cavity versus the lower part of the respiratory tract. ${ }^{20}$ This is also supported by the fact that the SARS-CoV-2 entry-associated genes ACE2 and TMPRSS2 are co-expressed in the nasal epithelial cells with genes involved in innate immunity. ${ }^{25}$ This evidence indicates that the initial infected site may be concealed by the light symptoms associated with it and that the nasal cavity is the potential initial viral base, providing puffs of viral particles to the lower respiratory tract through aspiration.

In COVID-19 patients, increased coagulated factors of D-dimers indicate that it is possible to 
develop a state of hypercoagulation. Furthermore, increased TNF- $\alpha$ and IL-1 could induce endothelial cells and lymphocytes to secrete nitric oxide and reactive oxygen species, which could affect blood coagulation, cause tissue damage and disseminated intravascular coagulation (DIC), ${ }^{26}$ and also increase the risk for thrombosis in parts of the vessels, lungs, catheters, and microvascular vessels in the toes. ${ }^{27-31}$ As more clinical and autopsy data become available, potential associations between COVID-19 and a variety of embolism syndromes have been cited, ${ }^{32-34}$ likely caused by immunological responses. The prevention of venous thromboembolism (VTE) is recommended only for those who experience an incident thromboembolic event or who are highly prone to have thromboembolic conditions. ${ }^{35}$

Evidence has shown that a high load of virus particles could be detected in the asymptomatic population, indicating the high infectivity and uncertain patent period of the coronavirus. One seroepidemiological study in the Spanish population indicated that at least one-third of the infected population were without typical symptoms of COVID-19. ${ }^{36} \mathrm{In}$ asymptomatic individuals and patients who recovered from COVID-19, levels of IgG and neutralizing antibodies decreased approximately $2-3$ months after initial infection with SARS-CoV-19, thus placing this population at risk of being superinfected. ${ }^{37}$ And, new strains of SARS-CoV-19 with certain mutations are likely to increase the risk of reinfection.

\section{AUTOPSY AND PATHOLOGICAL CHANGES IN COVID-19 PATIENTS}

SARS-CoV-2 infection and uncontrolled immune responses cause extensive damages in multiple organs of the severely infected. ${ }^{21}$ The clinical autopsy of 91 COVID-19 victims indicated that the most serious pathological changes were located in the respiratory system, with prominent and extensive pulmonary lesions. Respiratory tract lesions were caused by mucosa congestions in the trachea and bronchus, together with focal epithelial pneumocytes exfoliation. The diffuse alveolar lesions included a hyaline membrane formed by serous and fibrin exudate filling the cavity of the alveoli. Some septal rupture and cystic cavity of the alveoli were potentially caused by clear dilations of the alveoli. And, the thickening of the alveolar walls was possibly caused by stimulations of the accumulated alveolar fluids and hyperplasia of type II pneumocytes. Exudative inflammation also existed in the parenchymal areas, causing interstitial fibrosis and pulmonary carnification. In addition, focal pulmonary hemorrhagic infarction and thrombosis may be caused by the accumulation of mucin plugs in the microvessels. Coronavirus particles were seen at the site of pulmonary lesions, like in the tracheal and bronchial mucosa epithelia, and type II alveolar pneumocytes, together with the expression of ACE2 in these cells. Under a microscope, the infiltration of monocytes and macrophages was seen in the alveoli. ACE2 is expressed in the infiltrated macrophages. The formation of neutrophil extracellular traps (NETs) could strongly contribute to acute lung injury during virus infection, ${ }^{38-40}$ so dornase alfa was recommended to decrease mucus rigidity and accumulation in severe COVID-19 patients by degradation of the extracellular DNAs. ${ }^{41}$ The pathological changes of the accumulated pulmonary mucus were also evidenced in CT images. ${ }^{42}$ All the above pathological changes account for ARDS and greatly obstruct ventilation, especially in the small airways, eventually leading to the suffocation of COVID-19 patients.

Multiple types of cells within the affected organs are susceptible to impairment in COVID-19 patients. These damaged areas contain certain types of cells that could be directly infected by SARSCoV-2. A variety of pathological lesions were observed in organs of multiple systems in autopsy examinations. Viral particles could be detected in most of these impaired organs, including the trachea and lung in the respiratory system; the heart and blood vessels in the cardiovascular system; the spleen and lymph nodes in the immune system; the liver, esophagus, gastrointestinal tract, gallbladder, and pancreas in the digestive system; the kidney, breast, and testis in the urinary and genital systems; and the adrenal gland in the endocrine system. Some organ damage can be monitored via clinical testsfor example, kidney damage in COVID-19 patients could be indicated by continuously increasing levels of urea nitrogen and creatinine in severe cases. ${ }^{43}$ 
Thus the support of multiple organs should be emphasized and performed in clinic therapeutics for the severe COVID-19 patients. $^{21}$

\section{IMMUNOLOGICAL CHANGES IN COVID-19 PATIENTS}

Major immune responses in severe cases of COVID-19 are characterized as uncontrolled cytokine storm, exhausted lymphocytes, lymphopenia, and high NLR. ${ }^{44}$ Macrophages, neutrophils, and dendritic cells, together with the IgA-containing mucosal barriers, serve as the frontier barrier against SARS-CoV-2 infection. ${ }^{45}$ Impaired inflammatory responses in severe COVID-19 patients provided a distinct pattern of pathological progression, ${ }^{23,44,46-48}$ and the clinical symptoms of the noted immunological deteriorations are ARDS, septic shock, and multiple organ failure (MOF) ${ }^{49}$ The molecular mechanisms underlying immunological manifestations in severe COVID-19 patients should be further explored and clarified. Figure 2 illustrates the possible immunological changes that occur with potential symptoms.

\section{A. Cytokine Storm}

The serum proinflammatory cytokines and chemokines, such as IL-6, IL-1 $\beta$, IL-2R, IL-8, IL-17, G-CSF, GM-CSF, IP10, MCP-1, MIP-1 $\alpha$, and TNF- $\alpha$, were significantly increased in severe COVID-19 patients; these cytokines recruit immune cells through a positive feedback loop, eventually causing a cytokine storm..$^{23,50,51}$ The proliferation of macrophages in multiple tissues was observed, ${ }^{21}$ with the presence of IL-6 in plasma as a hallmark of severe infections. Cytokine storm was also found to be the major cause of morbidities in patients with SARS-CoV and MERS-CoV.52

IL-6 is a stable indicator of poor outcomes and severity, and the use of $\mathrm{mAb}$ tocilizumab against IL-6 has achieved positive clinical outcomes and benefits, even in severe cases of COVID-19.53,54 IL-6 inhibitors are not recommended at this time,

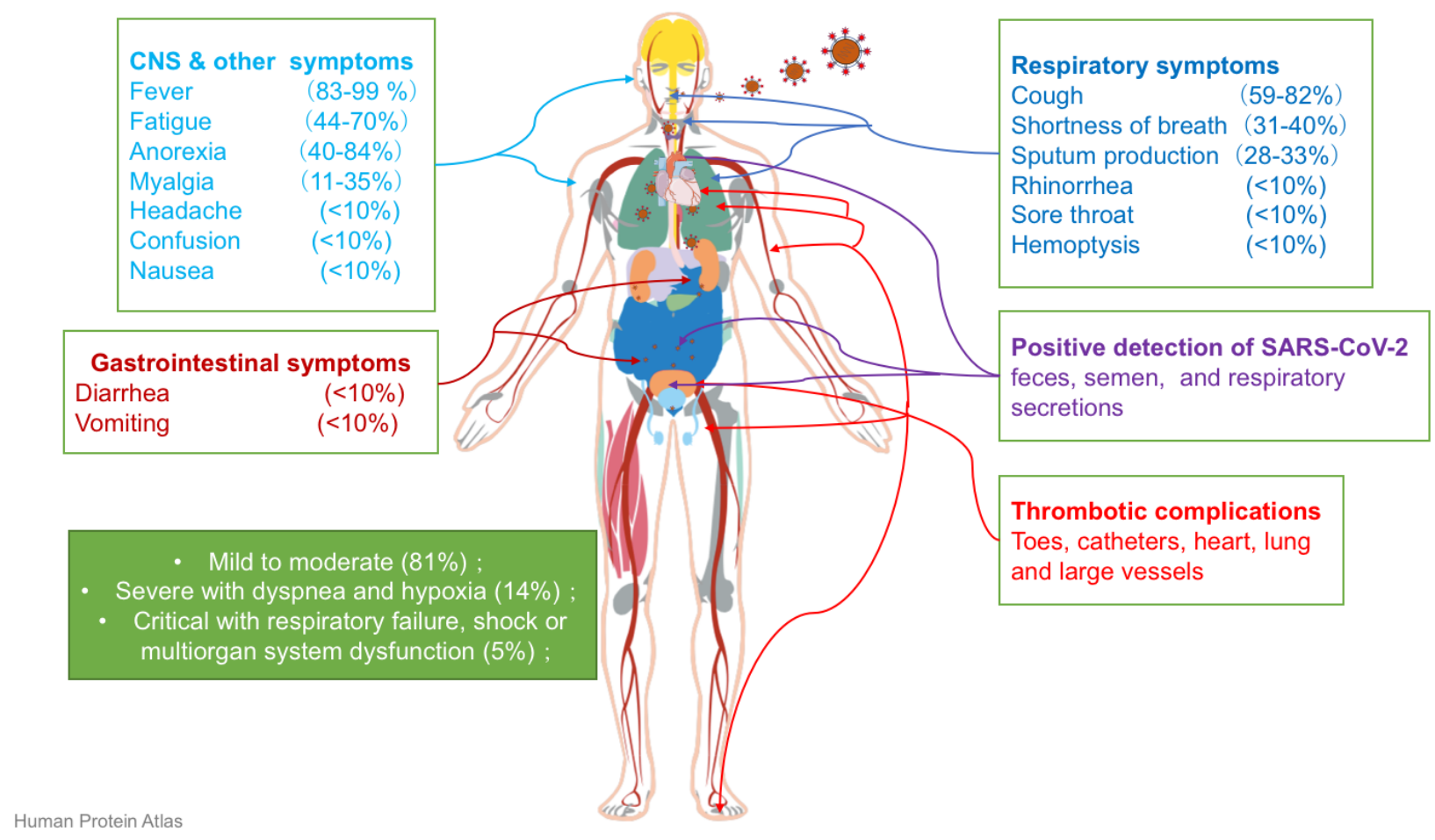

FIG. 2: Clinical symptoms and immunological changes in COVID-19 patients 
due to insufficient data from clinical trials. ${ }^{55}$ IL-6 could promote IL-17 production by $\mathrm{CD}^{+} \mathrm{T}$ cells, and STAT3 and NF- $\kappa$ B signaling pathways are involved in this process. ${ }^{56}$ Reciprocally, IL-17 induces the production of IL- 6 , IL- $1 \beta$, TNF- $\alpha$, G-CSF, GMCSF, IL-8, and MCP-1. IL-17 attracts infiltrations of neutrophils into alveolar tissues and remodels the airway, and it is essential for the functions of Th17 cells. ${ }^{57,58}$ IL-17 receptors are widely dispersed in multiple tissues, such as the kidney, intestine, and heart.

IL-1 is mainly produced by macrophages, neutrophil, monocytes, DC cells, and many other types of cells. It could activate and promote the functions of $\mathrm{CD}^{+}{ }^{+} \mathrm{T}$ cells, B cells, monocytes, and macrophages; attract neutrophils; and induce the secretion of inflammation mediators. However, due to insufficient clinical data and no data from clinical trials on the administration of anakinra (IL-1 inhibitors) in COVID-19 patients, there is no recommendation for the use of IL-1 inhibitors. ${ }^{59}$

IL-2 is produced by T cells and stimulates the proliferation of $\mathrm{T}$ cells. IL-2 could promote NK cell functions to kill virus-infected cells. Increased IL-2R could possibly inhibit the activation of T cells in COVID-19 patients. ${ }^{23}$

IL-8 is a neutrophil chemotactic factor produced by mono-macrophages. IP-10 (CXCL10, CRG-2) attracts Th1 cells, eosinophils, monocytes, and NK cells to the site of inflammation. It is upregulated by activated $\mathrm{T}$ cells, neutrophils, splenocytes, keratinocytes, osteoblasts, astrocytes, endothelial cells, smooth muscle cells, and pancreatic beta cells. MCP-1 (CCL2, JE) is a chemokine that binds to the receptor CCR2 and induces the chemoattraction of mononuclear cells. It induces the activation of monocyte, NK cells, lymphocytes, and basophil. Additionally, CCL2 promotes Th2 polarization in CD4 ${ }^{+}$ $\mathrm{T}$ cells and CCL2-mediated recruitment of monocytes to the inflammation sites. MIP-1 $\alpha$ (CCL3) acts as a chemoattractant to a variety of cells, including monocytes, T cells, B cells, and eosinophils. TNF- $\alpha$ is produced by monocytes and macrophage, and TNF- $\beta$ is majorly produced by activated T cells. TNF plays an important role in killing infected cells, inducing apoptosis and immune and inflammation responses. Increased GM-CSF in COVID-19 patients could stimulate stem cells to produce granulocytes (neutrophil, eosinophil, and basophils) and monocytes. Monocytes exit the circulation and migrate into tissue, whereupon they mature into macrophage. G-CSF has the same function, stimulating the hemopoietic progenitor cells to differentiate into granulocytes and monocytes. G-CSF and GM-CSF continuously stimulate hemopoietic progenitor cells to produce more lymphocytes to supply the shortage of immune cells for effective immune responses.

IFN-gamma is produced by $\mathrm{T}$ cells and NK cells. It plays an important antiviral role, and levels were decreased in COVID-19 patients. IFN responses in COVID-19 patients could potentially be interfered with, mainly by escaping viral recognition through PAMP ${ }^{60}$; evading activations of host responses through targeting the polyuridine sequences by coronavirus endoribonuclease ${ }^{61}$; methylation on ribose-2'-O of virus RNA, avoiding MDA5 recognition $^{6}$; and deubiquitination by papain-like proteinase to alleviate the response of interferon. ${ }^{62}$ Type I interferon could also be inhibited by $\mathrm{M}$ protein via deterring the assembling of the TBK1/IKK, TRAF3, and TANK complex, which may be the same as the process for SARS-CoV-2. ${ }^{63}$ The structural M protein of the coronavirus as a structural PAMP could enhance the responses of type I interferon through Toll-like receptor (TLR)-related mechanisms. ${ }^{64}$

The cytokine storm could lead to septic shock and whole system damage, particularly attracting the infiltration of neutrophils and macrophages into pulmonary alveoli and tract. Continuously expressed cytokines and chemokines could cause damages or even failures in multiple organs of COVID-19 patients. Glucocorticoid therapeutics against overactivated inflammation responses were recommended for severe cases. ${ }^{65}$

\section{B. Lymphopenia}

Lymphopenia is characterized by remarkably decreased T cells, B cells, and NK cells, along with decreased monocytes, eosinophils, and basophils. ${ }^{23}$ Reduced $\mathrm{CD}^{+}$and $\mathrm{CD} 8^{+} \mathrm{T}$ cells were observed in the tissue of the spleen and lymph nodes, and lymphocyte degeneration and necrosis were also observed. ${ }^{21}$ In the immune organs of the spleen and 
lymph nodes, virus particles and RNA were positively identified. Atrophic spleens with hemorrhage, anemic infarctions, and interstitial hyperplasia were visible. ${ }^{21}$ Lymph node damages were also observed in deceased patients, with apoptotic and necrotic lymphocytes, and hyperplasia interstitials dispersed in the paracortical and follicle areas. ${ }^{66}$ This evidence indicates that the immune organs were likely directly attacked by SARS-CoV-2, and the lymphocytes were deeply impaired or killed.

In terms of the most influenced subsets of $T$ cells, the counts of helper T cells, suppressor T cells, memory helper $\mathrm{T}$ cells, and regulatory $\mathrm{T}$ cells were all decreased, but a portion of naïve helper $\mathrm{T}$ cells were increased. ${ }^{23}$ The transformation of naïve $\mathrm{CD} 4^{+}$ $\mathrm{T}$ cells to effector and memory $\mathrm{T}$ cells is an essential process in adaptive immunology. A higher naïve $\mathrm{T}$ cell to memory $\mathrm{T}$ cell ratio indicates a poorly functioning immune system in severe COVID-19 patients. ${ }^{23}$ The counts of $\mathrm{CD}^{+} \mathrm{T}$ cells, $\mathrm{CD} 8^{+} \mathrm{T}$ cells, and regulatory $\mathrm{T}$ cells decreased; these subtypes of $\mathrm{T}$ cells play an important role in controlling overactivated innate immune responses in viral infection. ${ }^{67} \mathrm{NK}$ cells and $\mathrm{CD} 8^{+} \mathrm{T}$ cells exhibit functional exhaustion patterns with increased expression of NKG2A, PD-1, and TIM-3, which are exhaustion markers and return to normal in patients who have rehabilitated. ${ }^{68}$ This evidence indicates that the number of cytotoxic lymphocytes decreased and their functions were exhausted too.

The consumption or low production of lymphocytes, along with the exhausted functions of NK cells and $T$ cells, were indicative of impaired adaptive immune responses, which further aggravated uncontrolled inflammatory responses in severe COVID-19 patients. Several questions remain here: Why does lymphopenia happen? And where do the lymphocytes go? Furthermore, are they attracted to certain tissues and sites of inflammation and then trapped? It was reported that lymphocytes from recovered patients were not new cells after the viral infection; rather, because of the temporal sequestration of the lymphocytes, they were circulated between peripheral blood and tissues or organs. ${ }^{69}$ The results of an in vitro study indicated that SARS-CoV-2 infection could promote MAPK signaling and inhibit the mitotic kinases to arrest the cell cycle, ${ }^{14}$ possibly accounting for lymphopenia in COVID-19 patients. It is also possible that unknown factors induced more production of neutrophils and monocytes, which occupied too many biological resources for the progenitor cells to differentiate into lymphocytes. In addition, the lymphopenia and decreased adaptive immune responses were possibly caused by the downregulation of antigen presentation via MHC-I and MHC-II molecules after SARSCoV-2 infection. ${ }^{24}$ The exact molecular mechanisms should be discerned to clarify the immunopathological causes for the lymphopenia of COVID-19. Thus a specific strategy of therapeutics is proposed that involves enhancing adaptive immune functions, with a particular focus on the number and abilities of $\mathrm{T}$ cell subsets and controlling overactivated inflammatory responses like cytokine storms in COVID-19 patients.

\section{Adaptive Immune System and Antibodies}

IgM should be produced in the early stage of infection as the first apparent antibody, but IgG also appeared simultaneously in COVID-19 patients. IgG is the main driver of the body's immune response against microbes, binding the antigens on the infected cells. Increased IgG responses could activate the complement system and cause damages in the virally infected cells by the formation of MAC. Serum levels of $\operatorname{IgA}, \operatorname{IgG}$, and $\operatorname{IgM}$ and components of the complement system (as $\mathrm{C} 3$ and $\mathrm{C} 4$ ) were in the normal range in severe COVID-19 patients. $\mathrm{Mu}-$ cosal IgA or sIgA in the excretion form serves as the first physical barrier in the gastrointestinal and bronchus, which can bind the virus to avoid viral invasion. Increased IgA responses were observed in severe COVID-19 patients $^{70}$ and tended to be stronger than IgM responses. ${ }^{71,72}$

A higher titer of antibodies was reportedly correlated with the severity of COVID-19. In the early stage of the onset of COVID-19, SARS-CoV-2-specific antibodies could be detected in patients. ${ }^{73}$ The neutralizing antibodies in patients' plasma has been utilized for clinical therapeutics. ${ }^{74}$ In the recovery immunological processes, the role of antibodies is either protective or pathogenic, which remains 
uncertain. Thus the promotion of application of convalescent plasma for clinical therapeutic purposes is at high risk. Indeed, a potential antibody-dependent enhancement (ADE) has been shown in cases of MERS. ${ }^{44}$

The coagulation system, kinin system, fibrinolysis system, activated neutrophils, endothelial cells, and platelets, together with TNF- $\alpha$, IL-1, and IL-6, form an inflammation-mediated system in COVID-19 patients. An overactivated host immune system is responsible for the quick deterioration of COVID-19 patients. ${ }^{49}$ A sustained state of overactivated immune responses could lead to death if it is not alleviated immediately. ${ }^{22}$ Male patients with old age and basic chronic diseases like diabetes and hypertension are more likely to deteriorate; these complications worsen the disease outcomes, possibly due to this population's lower capacity for immunological defense. ${ }^{75}$ This evidence only further enhances recommendations for healthy living habits and regular exercise to boost immunological abilities.

\section{CURRENT ISSUES WITH POTENTIAL THERAPEUTICS FOR COVID-19}

As we have seen in the past few months, a lack of effective therapeutics has put the entire world population at risk for COVID-19. Many infected individuals will potentially move from mild to severe cases and ultimately death due to a general lack of sophisticated support facilities in many parts of the world. On June 30, 2020, the U.S. Centers for Disease Control and Prevention issued an "Interim Clinical Guidance for Management of Patients with Confirmed Coronavirus Disease" report, indicating that there are currently no antiviral drugs licensed by the U.S. Food and Drug Administration (FDA) for the treatment of patients with COVID-19. No available data from randomized controlled trials in humans support recommending any investigational therapeutics for patients with confirmed or suspected COVID-19, although the use of remdesivir has been cleared by the FDA as an Emergency Use Authorization (EUA). ${ }^{76}$ The currently adapted clinical management of COVID-19 patients is therefore mainly supportive care of complications, including advanced organ support with endotracheal intubation and mechanical ventilation and extracorporeal membrane oxygenation (ECMO), along with some effective or potentially effective therapeutics (Table $1)$.

As noted previously, among the therapeutics currently being used clinically, as well as those being investigated in clinical trials, is one promising antiviral drug known as remdesivir. On May 1, 2020, the FDA announced an EUA for remdesivir for the treatment of suspected or laboratory-confirmed COVID-19 in adults and children hospitalized with severe symptoms. Remdesivir was evidenced in a clinical trial to shorten the time to recovery in some patients, ${ }^{77}$ which is far from previous expectations. However, the clinical data on the safety and effectiveness of therapeutics with remdesivir for COVID-19 treatment are insufficient.

Another promising but disputed treatment is via an anti-malaria drug known as chloroquine, with many publications supporting the application for treatment of COVID-19. ${ }^{78}$ However, in June 2020, the FDA revoked the EUA for the drug,,$^{79,80}$ based on results from a large, randomized clinical trial in hospitalized patients. The FDA found the medicine to show no benefit for decreasing the likelihood of death or speeding recovery, which is quite astonishing and controversial based on previous evidence and publications.

In addition, the anti-inflammatory effects of glucocorticoids have been widely utilized to relieve inflammation severity in the lung for protective purposes. Some experts worried that the administration of steroids was of little benefit and might reversely suppress the overall immunological response and slow the clearance of viral particles from the body. ${ }^{81}$ Based on a randomized clinical trial, dexamethasone is the first medication shown to decrease mortalities by around one-third in COVID-19 patients. The administration of low-dose dexamethasone benefits severely ill COVID-19 patients but has shown no effect in mild to modest cases. ${ }^{65}$ This further indicates that the administration of steroids should be used selectively in only severe cases, rather than in all COVID-19 patients with differing degrees of severity. 
TABLE 1: Current therapeutic strategies for COVID-19: Recommendations, indications, and concerns

\begin{tabular}{|l|l|l|l|}
\hline \multicolumn{1}{|c|}{ Therapeutics } & Recommendations & \multicolumn{1}{|c|}{ Notes } & \multicolumn{1}{c|}{ Warnings } \\
\hline Remdesivir & $\begin{array}{l}\text { For hospitalized } \\
\text { patients with severe }\end{array}$ & $\begin{array}{l}\text { For patients with SpO2 } \leq 94 \% \text { on } \\
\text { ambient air or patients requiring } \\
\text { supplemental oxygen, patients on } \\
\text { mechanical ventilation or ECMO, } \\
\text { patients not intubated; duration of } \\
\text { therapy is 5 days }\end{array}$ & $\begin{array}{l}\text { Not clear for those who } \\
\text { are not improved and mild } \\
\text { to moderate COVID-19 } \\
\text { patients } \\
\text { deaths }{ }^{77}\end{array}$ \\
\hline Dexame effect on
\end{tabular}

A mixture of neutralizing antibodies is currently being developed, showing satisfactory results. Some COVID-19 vaccines have already passed Phase I/II clinical trials with satisfactory outcomes. The first vaccine to enter clinical trial was a recombinant adenovirus type-5 (Ad5)-vectored vaccine expressing the spike glycoprotein of one SARS-CoV-2 strain. This vaccine stimulated the production of significantly increased neutralizing antibodies in healthy volunteers, peaking 28 days after injection; aside from this, only mild and moderate adverse effects were observed. ${ }^{82}$ mRNA vaccines also have entered clinical trials. These vaccines exhibited several prioritized features, such as high biosecurity, mass production at high speed, and accessibility for a large population. ${ }^{83}$

It has recently been reported that the ancestral viruses of type $\mathrm{O}$ were replaced by the evolved viruses of type A2a, with a mutation S-D614G. ${ }^{84}$ The A2a type was discovered to be of high infectivity and fatality, sweeping across the globe, especially via the viral strains from Belgium, Spain, Italy, France, the Netherlands, and Switzerland, which top the death toll. Conversely, Kuwait and Germany, with a wild 
type of S-D614G, have fewer casualties.$^{85}$ In addition, other mutations also exist as potential strains of the SARS-CoV-2 with unknown infectivity. Two major problems are posed by the evolving mutations: one is that vaccine development may become cyclical work; the other is that new strains of the virus possessing mutations like S-D614G are a threat to recovered COVID-19 patients in China. Newly confirmed cases in the Xinfadi food market of Beijing were identified as possessing mutations, with potentially high mortalities and infectivity. This evidence indicates that subtypes of SARS-CoV-2 should be considered in future vaccine developments. ${ }^{86}$ There are several concerns regarding vaccine development, including the high failure rate of proposed vaccines, the fact that high numbers of neutralizing detectable antibodies do not necessarily translate to clinical protection, the continued appearance of genomic mutations, and the elusive nature of real protective efficiency.

Scientists throughout the world are working tirelessly to identify effective and safe therapeutics for the pneumonia caused by SARS-CoV-2, including vaccine development and drug development. Unfortunately, we have not yet reached a consensus about the most effective drugs or therapeutics to prevent the spread of this illness ${ }^{87}$ Without convincing positive results from rigorously designed clinical trials, the promotion of any therapeutics is irresponsible, including statements about the attenuation of clinical symptoms, fever reduction, and possible prevention of mild cases from increasing in severity to levels that are fatal for some. Consequently, immediate international action is called for to effectively address this pandemic and to better prepare nations for future pandemics.

\section{ACKNOWLEDGMENTS}

F.Y. Ma wrote the manuscript in its entirety; T.X. $\mathrm{Gu}$, S.M. Zhao, and K.D. Liu provided valuable suggestions; and Z.G. Dong designed the overall organization of this work, evaluating the rationale of the manuscript.

\section{REFERENCES}

1. WHO.int [Internet]. WHO coronavirus disease (COVID-
19) dashboard 2020. Updated 2020 Sep 25; cited 2020 Sep 25. Available from: https://covid19.who.int/.

2. Zhu N, Zhang D, Wang W, Li X, Yang B, Song J, Zhao X, Huang B, Shi W, Lu R, Niu P, Zhan F, Ma X, Wang D, Xu W, Wu G, Gao GF, Tan W, China Novel Coronavirus Investigating and Research Team. A novel coronavirus from patients with pneumonia in China, 2019. N Engl J Med. 2020 Feb 20;382(8):727-33.

3. Lu R, Zhao X, Li J, Niu P, Yang B, Wu H, Wang W, Song H, Huang B, Zhu N, Bi Y, Ma X, Zhan F, Wang L, Hu T, Zhou H, Hu Z, Zhou W, Zhao L, Chen J, Meng Y, Wang J, Lin Y, Yuan J, Xie Z, Ma J, Liu WJ, Wang D, Xu W, Holmes EC, Gao GF, Wu G, Chen W, Shi W, Tan W. Genomic characterisation and epidemiology of 2019 novel coronavirus: Implications for virus origins and receptor binding. Lancet. 2020 Feb 22;395(10224):565-74.

4. Hamming I, Cooper ME, Haagmans BL, Hooper NM, Korstanje R, Osterhaus AD, Timens W, Turner AJ, Navis $\mathrm{G}$, van Goor H. The emerging role of ACE2 in physiology and disease. J Pathol. 2007 May;212(1):1-11.

5. Chan JF, Kok KH, Zhu Z, Chu H, To KK, Yuan S, Yuen KY. Genomic characterization of the 2019 novel human-pathogenic coronavirus isolated from a patient with atypical pneumonia after visiting Wuhan. Emerg Microbe Infect. 2020 Jan 28;9(1):221-36. Erratum in: Emerg Microbe Infect. 2020 Dec;9(1):540.

6. Züst R, Cervantes-Barragan L, Habjan M, Maier R, Neuman BW, Ziebuhr J, Szretter KJ, Baker SC, Barchet W, Diamond MS, Siddell SG, Ludewig B, Thiel V. Ribose 2'-O-methylation provides a molecular signature for the distinction of self and non-self mRNA dependent on the RNA sensor Mda5. Nat Immunol. 2011 Feb;12(2):137-43.

7. Totura AL, Whitmore A, Agnihothram S, Schäfer A, Katze MG, Heise MT, Baric RS. Toll-like receptor 3 signaling via TRIF contributes to a protective innate immune response to severe acute respiratory syndrome coronavirus infection. mBio. 2015 May 26;6(3):e00638-15.

8. Zhou P, Yang XL, Wang XG, Hu B, Zhang L, Zhang W, Si HR, Zhu Y, Li B, Huang CL, Chen HD, Chen J, Luo Y, Guo H, Jiang RD, Liu MQ, Chen Y, Shen XR, Wang X, Zheng XS, Zhao K, Chen QJ, Deng F, Liu LL, Yan B, Zhan FX, Wang YY, Xiao GF, Shi ZL. A pneumonia outbreak associated with a new coronavirus of probable bat origin. Nature. 2020 Mar;579(7798):270-3.

9. Ge XY, Li JL, Yang XL, Chmura AA, Zhu G, Epstein JH, Mazet JK, Hu B, Zhang W, Peng C, Zhang YJ, Luo CM, Tan B, Wang N, Zhu Y, Crameri G, Zhang SY, Wang LF, Daszak P, Shi ZL. Isolation and characterization of a bat SARS-like coronavirus that uses the ACE2 receptor. Nature. 2013 Nov 28;503(7477):535-8.

10. Li MY, Li L, Zhang Y, Wang XS. Expression of the SARSCoV-2 cell receptor gene ACE2 in a wide variety of human tissues. Infect Dis Poverty. 2020;9(1):45.

11. Wang W, Xu Y, Gao R, Lu R, Han K, Wu G, Tan W. 
Detection of SARS-CoV-2 in different types of clinical specimens. JAMA. 2020 May 12;323(18):1843-4.

12. Li D, Jin M, Bao P, Zhao W, Zhang S. Clinical characteristics and results of semen tests among men with coronavirus disease 2019. JAMA Netw Open. 2020;3(5):e208292.

13. Chen Y, Chen L, Deng Q, Zhang G, Wu K, Ni L, Yang Y, Liu B, Wang W, Wei C, Yang J, Ye G, Cheng Z. The presence of SARS-CoV-2 RNA in the feces of COVID-19 patients. J Med Virol. 2020 Jul;92(7):833-40.

14. Bouhaddou M, Memon D, Meyer B, White KM, Rezelj VV, Correa Marrero M, Polacco BJ, Melnyk JE, Ulferts S, Kaake RM, Batra J, Richards AL, Stevenson E, Gordon DE, Rojc A, Obernier K, Fabius JM, Soucheray M, Miorin L, Moreno E, Koh C, Tran QD, Hardy A, Robinot R, Vallet T, Nilsson-Payant BE, Hernandez-Armenta C, Dunham A, Weigang S, Knerr J, Modak M, Quintero D, Zhou Y, Dugourd A, Valdeolivas A, Patil T, Li Q, Hüttenhain R, Cakir M, Muralidharan M, Kim M, Jang G, Tutuncuoglu B, Hiatt J, Guo JZ, Xu J, Bouhaddou S, Mathy CJP, Gaulton A, Manners EJ, Félix E, Shi Y, Goff M, Lim JK, McBride T, O’Neal MC, Cai Y, Chang JCJ, Broadhurst DJ, Klippsten S, De Wit E, Leach AR, Kortemme T, Shoichet B, Ott M, Saez-Rodriguez J, tenOever BR, Mullins RD, Fischer ER, Kochs G, Grosse R, García-Sastre A, Vignuzzi M, Johnson JR, Shokat KM, Swaney DL, Beltrao P, Krogan NJ. The global phosphorylation landscape of SARSCoV-2 infection. Cell. 2020 Aug 6;182(3):685-712.e19.

15. Lau SK, Woo PC, Li KS, Huang Y, Tsoi HW, Wong BH, Wong SS, Leung SY, Chan KH, Yuen KY. Severe acute respiratory syndrome coronavirus-like virus in Chinese horseshoe bats. Proc Natl Acad Sci U S A. 2005 Sep 27;102(39):14040-5.

16. Li W, Shi Z, Yu M, Ren W, Smith C, Epstein JH, Wang H, Crameri G, Hu Z, Zhang H, Zhang J, McEachern J, Field H, Daszak P, Eaton BT, Zhang S, Wang LF. Bats are natural reservoirs of SARS-like coronaviruses. Science. 2005 Oct 28;310(5748):676-9.

17. Hu B, Zeng LP, Yang XL, Ge XY, Zhang W, Li B, Xie JZ, Shen XR, Zhang YZ, Wang N, Luo DS, Zheng XS, Wang MN, Daszak P, Wang LF, Cui J, Shi ZL. Discovery of a rich gene pool of bat SARS-related coronaviruses provides new insights into the origin of SARS coronavirus. PLoS Pathog. 2017 Nov 30;13(11):e1006698.

18. Menachery VD, Yount BL Jr, Debbink K, Agnihothram S, Gralinski LE, Plante JA, Graham RL, Scobey T, Ge XY, Donaldson EF, Randell SH, Lanzavecchia A, Marasco WA, Shi ZL, Baric RS. A SARS-like cluster of circulating bat coronaviruses shows potential for human emergence. Nat Med. 2015 Dec;21(12):1508-13. Erratum in: Nat Med. 2016 Apr;22(4):446; Nat Med. 2020 Jul;26(7):1146.

19. CDC.gov. Interim clinical guidance for management of patients with confirmed coronavirus disease (COVID-19) 2020. Updated 2020 Sept 10; cited 2020 Sept 26. Available from https://www.cdc.gov/coronavirus/2019-ncov/ hcp/clinical-guidance-management-patients.html.
20. Hou YJ, Okuda K, Edwards CE, Martinez DR, Asakura T, Dinnon KH 3rd, Kato T, Lee RE, Yount BL, Mascenik TM, Chen G, Olivier KN, Ghio A, Tse LV, Leist SR, Gralinski LE, Schäfer A, Dang H, Gilmore R, Nakano S, Sun L, Fulcher ML, Livraghi-Butrico A, Nicely NI, Cameron M, Cameron C, Kelvin DJ, de Silva A, Margolis DM, Markmann A, Bartelt L, Zumwalt R, Martinez FJ, Salvatore SP, Borczuk A, Tata PR, Sontake V, Kimple A, Jaspers I, O’Neal WK, Randell SH, Boucher RC, Baric RS. SARS-CoV-2 reverse genetics reveals a variable infection gradient in the respiratory tract. Cell. $2020 \mathrm{Jul}$ 23;182(2):429-46.e14.

21. Bian X, The COVID-19 Pathology Team. Autopsy of COVID-19 victims in China. Natl Sci Rev. 2020;7(9): 1414-18.

22. Huang C, Wang Y, Li X, Ren L, Zhao J, Hu Y, Zhang L, Fan G, Xu J, Gu X, Cheng Z, Yu T, Xia J, Wei Y, Wu W, Xie X, Yin W, Li H, Liu M, Xiao Y, Gao H, Guo L, Xie J, Wang G, Jiang R, Gao Z, Jin Q, Wang J, Cao B. Clinical features of patients infected with 2019 novel coronavirus in Wuhan, China. Lancet. 2020 Feb 15;395(10223):497506. Erratum in: Lancet. 2020 Jan 30.

23. Qin C, Zhou L, Hu Z, Zhang S, Yang S, Tao Y, Xie C, Ma K, Shang K, Wang W, Tian DS. Dysregulation of immune response in patients with coronavirus 2019 (COVID-19) in Wuhan, China. Clin Infect Dis. 2020 Jul 28;71(15): 762-8.

24. Paces J, Strizova Z, Smrz D, Cerny J. COVID-19 and the immune system. Physiol Res. 2020;69(3):379-88.

25. Sungnak W, Huang N, Bécavin C, Berg M, Queen R, Litvinukova M, Talavera-López C, Maatz H, Reichart D, Sampaziotis F, Worlock KB, Yoshida M, Barnes JL, HCA Lung Biological Network. SARS-CoV-2 entry factors are highly expressed in nasal epithelial cells together with innate immune genes. Nat Med. 2020 May;26(5):681-7.

26. Lin L, Lu L, Cao W, Li T. Hypothesis for potential pathogenesis of SARS-CoV-2 infection: A review of immune changes in patients with viral pneumonia. Emerg Microbe Infect. 2020;9(1):727-32.

27. Bikdeli B, Madhavan MV, Jimenez D, Chuich T, Dreyfus I, Driggin E, Nigoghossian C, Ageno W, Madjid M, Guo Y, Tang LV, Hu Y, Giri J, Cushman M, Quéré I, Dimakakos EP, Gibson CM, Lippi G, Favaloro EJ, Fareed J, Caprini JA, Tafur AJ, Burton JR, Francese DP, Wang EY, Falanga A, McLintock C, Hunt BJ, Spyropoulos AC, Barnes GD, Eikelboom JW, Weinberg I, Schulman S, Carrier M, Piazza G, Beckman JA, Steg PG, Stone GW, Rosenkranz S, Goldhaber SZ, Parikh SA, Monreal M, Krumholz HM, Konstantinides SV, Weitz JI, Lip GYH. COVID-19 and thrombotic or thromboembolic disease: Implications for prevention, antithrombotic therapy, and follow-up: JACC State-of-the-Art Review. J Am Coll Cardiol. 2020 Jun 16;75(23):2950-73.

28. Cannegieter SC, Klok FA. COVID-19 associated coagulopathy and thromboembolic disease: Commentary on 
an interim expert guidance. Res Pract Thromb Haemost. 2020;4(4):439-45.

29. Helms J, Tacquard C, Severac F, Leonard-Lorant I, Ohana M, Delabranche X, Merdji H, Clere-Jehl R, Schenck M, Fagot Gandet F, Fafi-Kremer S, Castelain V, Schneider F, Grunebaum L, Anglés-Cano E, Sattler L, Mertes PM, Meziani F, CRICS TRIGGERSEP Group (Clinical Research in Intensive Care and Sepsis Trial Group for Global Evaluation and Research in Sepsis). High risk of thrombosis in patients with severe SARS-CoV-2 infection: A multicenter prospective cohort study. Intensive Care Med. 2020 Jun;46(6):1089-98.

30. Grillet F, Behr J, Calame P, Aubry S, Delabrousse E. Acute pulmonary embolism associated with COVID-19 pneumonia detected by pulmonary CT angiography. Radiology. 2020;296(3):e186-8.

31. Magro C, Mulvey JJ, Berlin D, Nuovo G, Salvatore S, Harp J, Baxter-Stoltzfus A, Laurence J. Complement associated microvascular injury and thrombosis in the pathogenesis of severe COVID-19 infection: A report of five cases. Transl Res. 2020 Jun;220:1-13.

32. Danzi GB, Loffi M, Galeazzi G, Gherbesi E. Acute pulmonary embolism and COVID-19 pneumonia: A random association? Eur Heart J. 2020;41(19):1858.

33. Klok FA, Kruip MJHA, van der Meer NJM, Arbous MS, Gommers DAMPJ, Kant KM, Kaptein FHJ, van Paassen J, Stals MAM, Huisman MV, Endeman H. Incidence of thrombotic complications in critically ill ICU patients with COVID-19. Thromb Res. 2020 Jul;191:145-7.

34. Wichmann D, Sperhake JP, Lütgehetmann M, Steurer S, Edler C, Heinemann A, Heinrich F, Mushumba H, Kniep I, Schröder AS, Burdelski C, de Heer G, Nierhaus A, Frings D, Pfefferle S, Becker H, Bredereke-Wiedling $\mathrm{H}$, de Weerth A, Paschen HR, Sheikhzadeh-Eggers S, Stang A, Schmiedel S, Bokemeyer C, Addo MM, Aepfelbacher M, Püschel K, Kluge S. Autopsy findings and venous thromboembolism in patients with COVID-19: A prospective cohort study. Ann Intern Med. 2020 Aug 18;173(4):268-77.

35. NIH.gov [Internet]. Antithrombotic therapy in patients with COVID-19 2020. Updated 2020 May 12; cited 2020 Sept 26. Available from: https://www.covid19treatmentguidelines.nih.gov/adjunctive-therapy/antithrombotictherapy/.

36. Pollán M, Pérez-Gómez B, Pastor-Barriuso R, Oteo J, Hernán MA, Pérez-Olmeda M, Sanmartín JL, Fernández-García A, Cruz I, Fernández de Larrea N, Molina M, Rodríguez-Cabrera F, Martín M, Merino-Amador P, León Paniagua J, Muñoz-Montalvo JF, Blanco F, Yotti R, ENE-COVID Study Group. Prevalence of SARS-CoV-2 in Spain (ENE-COVID): A nationwide, population-based seroepidemiological study. Lancet. 2020 Aug 22;396(10250):535-44.

37. Long QX, Tang XJ, Shi QL, Li Q, Deng HJ, Yuan J, Hu JL, Xu W, Zhang Y, Lv FJ, Su K, Zhang F, Gong J, Wu
B, Liu XM, Li JJ, Qiu JF, Chen J, Huang AL. Clinical and immunological assessment of asymptomatic SARSCoV-2 infections. Nat Med. 2020 Aug;26(8):1200-4.

38. Liu S, Su X, Pan P, Zhang L, Hu Y, Tan H, Wu D, Liu B, Li H, Li H, Li Y, Dai M, Li Y, Hu C, Tsung A. Neutrophil extracellular traps are indirectly triggered by lipopolysaccharide and contribute to acute lung injury. Sci Rep. 2016 Nov 16;6:37252.

39. Narasaraju T, Yang E, Samy RP, Ng HH, Poh WP, Liew AA, Phoon MC, van Rooijen N, Chow VT. Excessive neutrophils and neutrophil extracellular traps contribute to acute lung injury of influenza pneumonitis. Am J Pathol. 2011 Jul;179(1):199-210.

40. Lefrançais E, Mallavia B, Zhuo H, Calfee CS, Looney MR. Maladaptive role of neutrophil extracellular traps in pathogen-induced lung injury. JCI Insight. 2018;3(3):e98178.

41. Earhart AP, Holliday ZM, Hofmann HV, Schrum AG. Consideration of dornase alfa for the treatment of severe COVID-19 acute respiratory distress syndrome. New Microbe New Infect. 2020;35:100689.

42. Chung M, Bernheim A, Mei X, Zhang N, Huang M, Zeng X, Cui J, Xu W, Yang Y, Fayad ZA, Jacobi A, Li K, Li S, Shan H. CT imaging features of 2019 novel coronavirus (2019-nCoV). Radiology. 2020 Apr;295(1):202-7.

43. Wang D, Hu B, Hu C, Zhu F, Liu X, Zhang J, Wang B, Xiang H, Cheng Z, Xiong Y, Zhao Y, Li Y, Wang X, Peng Z. Clinical characteristics of 138 hospitalized patients with 2019 novel coronavirus-infected pneumonia in $\mathrm{Wu}-$ han, China. JAMA. 2020 Mar 17;323(11):1061-9.

44. Cao X. COVID-19: Immunopathology and its implications for therapy. Nat Rev Immunol. 2020;20(5):269-70.

45. Barton LM, Duval EJ, Stroberg E, Ghosh S, Mukhopadhyay S. COVID-19 autopsies, Oklahoma, USA. Am J Clin Pathol. 2020;153(6):725-33.

46. Zhang B, Zhou X, Zhu C, Song Y, Feng F, Qiu Y, Feng J, Jia Q, Song Q, Zhu B, Wang J. Immune phenotyping based on the neutrophil-to-lymphocyte ratio and IgG level predicts disease severity and outcome for patients with COVID-19. Front Mol Biosci. 2020 Jul 3;7:157.

47. Chen X, Ling J, Mo P, Zhang Y, Jiang Q, Ma Z, Cao Q, Hu W, Zou S, Chen L, Yao L, Luo M, Chen T, Deng L, Liang K, Song S, Yang R, Zheng R, Gao S, Gui X, Ke H, Hou W, Lundkvist A, Xiong Y. Restoration of leukomonocyte counts is associated with viral clearance in COVID-19 hospitalized patients. medRxiv. 2020 Mar;20030437.

48. Zheng M, Gao Y, Wang G, Song G, Liu S, Sun D, Xu Y, Tian Z. Functional exhaustion of antiviral lymphocytes in COVID-19 patients. Cell Mol Immunol. 2020 May;17(5):533-35.

49. Xu Z, Shi L, Wang Y, Zhang J, Huang L, Zhang C, Liu S, Zhao P, Liu H, Zhu L, Tai Y, Bai C, Gao T, Song J, Xia P, Dong J, Zhao J, Wang FS. Pathological findings of COVID-19 associated with acute respiratory distress syndrome. Lancet Respir Med. 2020 Apr;8(4):420-22. Erratum in: Lancet Respir Med. 2020 Feb 25. 
51. Tan M, Liu Y, Zhou R, Deng X, Li F, Liang K, Shi Y. Immunopathological characteristics of coronavirus disease 2019 cases in Guangzhou, China. Immunology. 2020 Jul;160(3):261-8.

52. Channappanavar R, Perlman S. Pathogenic human coronavirus infections: Causes and consequences of cytokine storm and immunopathology. Semin Immunopathol. 2017;39(5):529-39.

53. Zhang S, Li L, Shen A, Chen Y, Qi Z. Rational use of tocilizumab in the treatment of novel coronavirus pneumonia. Clin Drug Investig. 2020;40(6):511-18.

54. Xu X, Han M, Li T, Sun W, Wang D, Fu B, Zhou Y, Zheng X, Yang Y, Li X, Zhang X, Pan A, Wei H. Effective treatment of severe COVID-19 patients with tocilizumab. Proc Natl Acad Sci U S A. 2020 May 19;117(20):10970-5.

55. NIH.gov [Internet]. Interleukin-6 inhibitors 2020. Updated 2020 Aug 27; cited 2020 Sept 26. Available from: https:// www.covid19treatmentguidelines.nih.gov/immunebased-therapy/immunomodulators/interleukin-6inhibitors/.

56. Cho ML, Kang JW, Moon YM, Nam HJ, Jhun JY, Heo SB, Jin HT, Min SY, Ju JH, Park KS, Cho YG, Yoon $\mathrm{CH}$, Park SH, Sung YC, Kim HY. STAT3 and NF-kappaB signal pathway is required for IL-23-mediated IL-17 production in spontaneous arthritis animal model IL-1 receptor antagonist-deficient mice. J Immunol. 2006 May 1;176(9):5652-61.

57. Aggarwal S, Gurney AL. IL-17: Prototype member of an emerging cytokine family. J Leukoc Biol. 2002;71(1):1-8.

58. Aggarwal S, Ghilardi N, Xie MH, de Sauvage FJ, Gurney AL. Interleukin-23 promotes a distinct CD4 T cell activation state characterized by the production of interleukin-17. J Biol Chem. 2003;278(3):1910-14.

59. NIH.gov [Internet]. Interleukin-1 inhibitors 2020. Updated $2020 \mathrm{Jul}$ 17; cited 2020 Sept 26. Available from: https://www. covid19treatmentguidelines.nih.gov/immune-based-therapy/ immunomodulators/interleukin-1-inhibitors/.

60. Frieman M, Heise M, Baric R. SARS coronavirus and innate immunity. Virus Res. 2008;133(1):101-12.

61. Hackbart M, Deng X, Baker SC. Coronavirus endoribonuclease targets viral polyuridine sequences to evade activating host sensors. Proc Natl Acad Sci U S A. 2020;117(14):8094-103.

62. Clementz MA, Chen Z, Banach BS, Wang Y, Sun L, Ratia K, Baez-Santos YM, Wang J, Takayama J, Ghosh AK, Li K, Mesecar AD, Baker SC. Deubiquitinating and interferon antagonism activities of coronavirus papain-like proteases. J Virol. 2010 May;84(9):4619-29.

63. Siu KL, Kok KH, Ng MH, Poon VK, Yuen KY, Zheng BJ, Jin DY. Severe acute respiratory syndrome coronavirus M protein inhibits type I interferon production by impeding the formation of TRAF3.TANK.TBK1/IKK epsilon complex. J Biol Chem. 2009 Jun 12;284(24):16202-9.

64. Wang Y, Liu L. The membrane protein of severe acute respiratory syndrome coronavirus functions as a novel cytosolic pathogen-associated molecular pattern to promote beta interferon induction via a toll-like-receptor-related TRAF3-independent mechanism. mBio. 2016;7(1):e01872-15.

65. Ledford H. Coronavirus breakthrough: Dexamethasone is first drug shown to save lives. Nature. 2020;582(7813):469.

66. Chen Y, Feng Z, Diao B, Wang R, Wang G, Wang C, Tan Y, Liu L, Wang C, Liu Y, Liu Y, Yuan Z, Ren L, Wu Y. The novel severe acute respiratory syndrome coronavirus 2 (SARS-CoV-2) directly decimates human spleens and lymph nodes. medRxiv. 2020 Mar;20045427.

67. Shaw AC, Goldstein DR, Montgomery RR. Age-dependent dysregulation of innate immunity. Nat Rev Immunol. 2013;13(12):875-87.

68. Zheng M, Gao Y, Wang G, Song G, Liu S, Sun D, Xu Y, Tian Z. Functional exhaustion of antiviral lymphocytes in COVID-19 patients. Cell Mol Immunol. 2020 May;17(5):533-5.

69. Xie J, Fan HW, Li TS, Qiu ZF, Han Y. Dynamic changes of $\mathrm{T}$ lymphocyte subsets in the long-term follow-up of severe acute respiratory syndrome patients. Zhongguo Yi Xue Ke Xue Yuan Xue Bao. 2006;28(2):253-5.

70. Okba NMA, Müller MA, Li W, Wang C, GeurtsvanKessel $\mathrm{CH}$, Corman VM, Lamers MM, Sikkema RS, de Bruin E, Chandler FD, Yazdanpanah Y, Le Hingrat Q, Descamps D, Houhou-Fidouh N, Reusken CBEM, Bosch BJ, Drosten C, Koopmans MPG, Haagmans BL. Severe acute respiratory syndrome coronavirus 2: Specific antibody responses in coronavirus disease patients. Emerg Infect Dis. 2020 Jul;26(7):1478-88.

71. Padoan A, Sciacovelli L, Basso D, Negrini D, Zuin S, Cosma C, Faggian D, Matricardi P, Plebani M. IgA-Ab response to spike glycoprotein of SARS-CoV-2 in patients with COVID-19: A longitudinal study. Clin Chim Acta. 2020 Aug;507:164-6.

72. Rizzo P, Vieceli Dalla Sega F, Fortini F, Marracino L, Rapezzi C, Ferrari R. COVID-19 in the heart and the lungs: Could we "notch" the inflammatory storm? Basic Res Cardiol. 2020;115(3):31.

73. Zhao R, Li M, Song H, Chen J, Ren W, Feng Y, Gao GF, Song J, Peng Y, Su B, Guo X, Wang Y, Chen J, Li J, Sun H, Bai Z, Cao W, Zhu J, Zhang Q, Sun Y, Sun S, Mao X, Su J, Chen X, He A, Gao W, Jin R, Jiang Y, Sun L. Early detection of SARS-CoV-2 antibodies in COVID-19 patients as a serologic marker of infection. Clin Infect Dis. 2020 May 1:ciaa523.

74. Shen C, Wang Z, Zhao F, Yang Y, Li J, Yuan J, Wang F, Li D, Yang M, Xing L, Wei J, Xiao H, Yang Y, Qu J, Qing L, Chen L, Xu Z, Peng L, Li Y, Zheng H, Chen F, Huang K, Jiang Y, Liu D, Zhang Z, Liu Y, Liu L. Treatment of 5 critically ill patients with COVID-19 with convalescent plasma. JAMA. 2020 Apr 28;323(16):1582-9.

75. Marquez EJ, Trowbridge J, Kuchel GA, Banchereau J, Ucar D. The lethal sex gap: COVID-19. Immun Ageing. 2020;17:13. 
76. CDC.gov [Internet]. Interim clinical guidance for management of patients with confirmed coronavirus disease (COVID-19) 2020. Updated 2020 Sept 10; cited 2020 Sept 26. Available from: https://www.cdc.gov/ coronavirus/2019-ncov/hcp/clinical-guidance-management-patients.html.

77. Beigel JH, Tomashek KM, Dodd LE, Mehta AK, Zingman BS, Kalil AC, Hohmann E, Chu HY, Luetkemeyer A, Kline S, de Castilla DL, Finberg RW, Dierberg K, Tapson V, Hsieh L, Patterson TF, Paredes R, Sweeney DA, Short WR, Touloumi G, Lye DC, Ohmagari N, Oh M-D, Ruiz-Palacios GM, Benfield T, Fätkenheuer G, Kortepeter MG, Atmar RL, Creech CB, Lundgren J, Babiker AG, Pett S, Neaton JD, Burgess TH, Bonnett T, Green M, Makowski M, Osinusi A, Nayak S, Lane HC, ACTT-1 Study Group Members. Remdesivir for the treatment of COVID-19: Preliminary report. N Engl J Med. 2020:oa2007764.

78. Gao J, Tian Z, Yang X. Breakthrough: Chloroquine phosphate has shown apparent efficacy in treatment of COVID-19 associated pneumonia in clinical studies. Biosci Trends. 2020;14(1):72-3.

79. FDA.gov [Internet]. Coronavirus (COVID-19) update: FDA revokes emergency use authorization for chloroquine and hydroxychloroquine 2020. Updated 2020 Jun 15; cited 2020 Sept 25. Available from: https://www.fda.gov/news-events/ press-announcements/coronavirus-covid-19-update-fda-revokes-emergency-use-authorization-chloroquine-and.

80. Meo SA, Klonoff DC, Akram J. Efficacy of chloroquine and hydroxychloroquine in the treatment of COVID-19. Eur Rev Med Pharmacol Sci. 2020;24(8):4539-47.

81. Ledford H. How does COVID-19 kill? Uncertainty is hampering doctors' ability to choose treatments. Nature. 2020;580(7803):311-2.

82. Zhu FC, Li YH, Guan XH, Hou LH, Wang WJ, Li JX, Wu SP, Wang BS, Wang Z, Wang L, Jia SY, Jiang HD, Wang L, Jiang T, Hu Y, Gou JB, Xu SB, Xu JJ, Wang XW, Wang W, Chen W. Safety, tolerability, and immunogenicity of a recombinant adenovirus type-5 vectored COVID-19 vaccine: A dose-escalation, open-label, non-randomised, firstin-human trial. Lancet. 2020 Jun 13;395(10240):1845-54.

83. Wang F, Kream RM, Stefano GB. An evidence based perspective on mRNA-SARS-CoV-2 vaccine development. Med Sci Monit. 2020;26:e924700.
84. Biswas NK, Majumder PP. Analysis of RNA sequences of 3636 SARS-CoV-2 collected from 55 countries reveals selective sweep of one virus type. Indian J Med Res. 2020;151(5):450-8.

85. Eaaswarkhanth M, Al Madhoun A, Al-Mulla F. Could the D614G substitution in the SARS-CoV-2 spike (S) protein be associated with higher COVID-19 mortality? Int J Infect Dis. 2020;96:459-60.

86. Morais Júnior IJ, Polveiro RC, Souza GM, Bortolin DI, Sassaki FT, Lima ATM. The global population of SARSCoV-2 is composed of six major subtypes. bioRxiv. 2020 Apr;040782.

87. Raoult D, Hsueh PR, Stefani S, Rolain JM. COVID-19 therapeutic and prevention. Int $\mathrm{J}$ Antimicrob Agents. 2020;55(4):105937.

88. NIH.gov [Internet]. Convalescent plasma 2020. Updated 2020 Jul 17; cited 2020 Sept 25. Available from: https:// www.covid19treatmentguidelines.nih.gov/immunebased-therapy/blood-derived-products/convalescentplasma/.

89. NHC.gov [Internet]. Clinical therapeutics of convalescent plasma from COVID-19 (trial version 2) 2020. Updated 2020 Mar 4; cited 2020 Sept 25. Available from: http:// www.nhc.gov.cn/xcs/fkdt/202003/ce59f4f132f644bf898ece0b0eece50b.shtml.

90. Bloch EM, Shoham S, Casadevall A, Sachais BS, Shaz B, Winters JL, van Buskirk C, Grossman BJ, Joyner M, Henderson JP, Pekosz A, Lau B, Wesolowski A, Katz L, Shan H, Auwaerter PG, Thomas D, Sullivan DJ, Paneth N, Gehrie E, Spitalnik S, Hod EA, Pollack L, Nicholson WT, Pirofski LA, Bailey JA, Tobian AA. Deployment of convalescent plasma for the prevention and treatment of COVID-19. J Clin Invest. 2020 Jun 1;130(6): 2757-65.

91. Clinicaltrials.gov [Internet]. Clinical trials of vaccines for COVID-19 2020. Updated 2020 Sept 25; cited 2020 Sept 25. Available from: https://clinicaltrials.gov/ct2/results? term $=$ vaccine $\&$ cond $=$ COVID -19 .

92. NIH.gov [Internet]. Immunomodulators under evaluation for the treatment of COVID-19 2020. Updated 2020 Aug 27; 2020 Sept 25. Available from: https://www.covid19treatmentguidelines.nih.gov/ immune-based-therapy/immunomodulators/. 